\title{
Evaluating sugarcane (Saccharum sp.) cultivars for water deficit tolerance using some key physiological markers
}

\author{
Suriyan Cha-um¹,*, Sukanya Wangmoon², Chareerat Mongkolsiriwatana², \\ Muhammad Ashraf ${ }^{3}$, Chalermpol Kirdmanee \\ ${ }^{1}$ National Center for Genetic Engineering and Biotechnology (BIOTEC), National Science and Technology Development \\ Agency (NSTDA), 113 Thailand Science Park, Paholyothin Road, Klong 1, Klong Luang, Pathumthani 12120, Thailand; ${ }^{2}$ Division \\ of Genetics, Faculty of Liberal Arts and Science, Kasetsart University, Kampangsan Campus, Nakhon Pathom 73140, Thailand; \\ ${ }^{3}$ Department of Botany, Faculty of Science, University of Agriculture, Faisalabad 38040, Pakistan \\ *E-mail: suriyanc@biotec.or.th Fax: +662-564-6707
}

Received March 23, 2012; accepted July 26, 2012 (Edited by H. Shimada)

\begin{abstract}
Seven sugarcane (Saccharum sp.) commercial cultivars, viz., UT-94-2-483, LK92-11, K84-200, K97-32, K95-84, K88-92 and K 92-80, originally derived from meristem cuttings were subjected to simulated osmotic stress (as $200 \mathrm{mM}$ mannitol) under controlled environmental conditions. Proline content in the leaf tissues of all cultivars except K92-80, increased in plants subjected to mannitol-induced osmotic stress. Chlorophyll $a\left(\mathrm{Chl}_{a}\right)$, chlorophyll $b\left(\mathrm{Chl}_{b}\right)$, total chlorophyll (TC), maximum quantum yield of PSII $\left(\mathrm{F}_{\mathrm{v}} / \mathrm{F}_{\mathrm{m}}\right)$, and photon yield of PSII $\left(\Phi_{\mathrm{PSII}}\right)$ of all seven cultivars decreased under osmotic stress resulting in a reduction in net-photosynthetic rate $\left(\mathrm{P}_{n}\right)$. A positive correlation was found between $\mathrm{F}_{\mathrm{v}} /$ $\mathrm{F}_{\mathrm{m}}$ and $\Phi_{\mathrm{PSII}}$, proline content and non-photochemical quenching $(\mathrm{NPQ}), \Phi_{\mathrm{PSII}}$ and $\mathrm{P}_{\mathrm{n}}$, and $\mathrm{P}_{\mathrm{n}}$ and plant dry weight in the sugarcane cultivars. Based upon Ward's multivariate cluster analyses of data for proline content, photosynthetic capacity, chlorophyll fluorescence, and growth inhibition, three cultivars (K88-92, K92-80 and UT-94-2-483) were identified as water deficit sensitive, whereas four (K84-200, K95-84, K97-32 and LK92-11) as water deficit tolerant. These observations on different cultivar's sensitivity/tolerance were confirmed by growth and yield attributes measured in a field trial. The plant dry weight (in vitro) correlated positively with total stalk weight of sugarcane cultivars
\end{abstract}

Key words: Sugarcane, osmotic stress response, growth, photosynthetic abilities, free proline, Ward's cluster analysis.

Sugarcane (Saccharum sp.) is one of the most important sugar producing crops and plays a key role in ethanol production in most of the tropical and subtropical countries (Waclawovsky et al. 2010). Being a $\mathrm{C}_{4}$ plant with long life cycle, it utilizes high amount of water, nutrients, $\mathrm{CO}_{2}$ and light energy to produce a considerably high biomass (Carr and Knox 2011). Generally, sugarcane cultivation is carried out in areas with sufficient amount of good quality water available for irrigation. However, in most of the areas sugarcane crop does not receive adequate supply of water during its entire growth period resulting in reduced yield (InmanBamber 2004; Silva et al. 2008; de Silva and de Costa 2009; Ishaq and Olaoye 2009).

Water deficit is one of the most vital abiotic stresses limiting crop productivity (Ashraf, 2010; Ashraf et al. 2011), including that of sugarcane (Hemaprabha et al. 2004; Silva et al. 2008; Ishaq and Olaoye 2009). The reduction in plant growth is the first response of sugarcane to water deficit; however, enhanced production of organic osmolytes (such as glycinebetaine and proline), reactive oxygen species (ROS), and reduced photosynthetic capacity have been reported as physiological and biochemical responses of sugarcane to osmotic stress conditions (Azevedo et al. 2011; Queiroz et al. 2011; Thapa et al. 2011). Nevertheless, crop improvement for drought tolerance trait is a viable approach for sugarcane production. In this regard, the screening of germplasm for drought tolerance, though a simple and straight-forward approach, yet is costly and time-consuming practice. Alternatively, in vitro screening is a well established simple, rapid and low cost tool by which large populations of breeding lines can easily be screened (Rai et al. 2011; Suprasanna et al. 2011).

In most of previous studies, a single parameter has been used as a selection criterion for screening sugarcane germplasm for drought tolerance (Wagih et al. 2003; Hemaprabha et al. 2004; Hemaprabha et al. 2006) and the results have not been so encouraging in terms of identification of tolerant genotypes. Thus, the aim of the present investigation was to compare different (seven) sugarcane cultivars grown in vitro and field conditions for drought tolerance screening using the Ward's cluster analysis based on a number of physiological, biochemical 
and morphological parameters.

\section{Materials and methods}

\section{In vitro evaluation-Plant materials and osmotic stress treatments}

Seven sugarcane (Saccharum sp.) cultivars, viz., UT-94-2483, LK92-11, K84-200, K97-32, K95-84, K88-92 and K9280 (commonly grown in Thailand), derived from meristem cutting were grown on MS media (Murashige and Skoog 1962) supplemented with $3 \%$ sucrose, $8.88 \mu \mathrm{M}$ benzyl adenine (BA), and $0.25 \%$ Phytage $^{\circledR}$ for 42 days. After separating the shoots from roots, the latter were placed on MS medium supplemented with $2.46 \mu \mathrm{M}$ indole butyric acid (IBA) for 14 days. Plantlets were grown under ambient temperature $\left(25 \pm 2^{\circ} \mathrm{C}\right), 60 \pm 5 \%$ relative humidity (RH), and $60 \pm 5 \mu \mathrm{mol} \mathrm{m}^{-2} \mathrm{~s}^{-1}$ photosynthetic photon flux density (PPFD) provided by fluorescent lamps with a $16 \mathrm{~h} \mathrm{day}^{-1}$ photoperiod. After 14 days, the plantlets were shifted to MS sugar-free liquid medium in a growth incubator maintained at $25 \pm 2^{\circ} \mathrm{C}, 60 \pm 5 \% \mathrm{RH}$, and $120 \pm 5 \mu \mathrm{mol} \mathrm{m}^{-2} \mathrm{~s}^{-1}$ PPFD at $16 \mathrm{hday}^{-1}$ photoperiod and $\mathrm{CO}_{2}$ enrichment at $1,000 \pm 100 \mu \mathrm{mol} \mathrm{CO}_{2} \mathrm{~mol}^{-1}$ (Cha-um et al. 2003). Mannitol $(200 \mathrm{mM})$ was added to the culture medium to induce osmotic stress. After 14 days different physiological and biochemical parameters including proline content, photosynthetic pigments, chlorophyll fluorescence, and net-photosynthetic rate $\left(\mathrm{P}_{\mathrm{n}}\right)$, and the growth performance was measured in sugarcane plantlets. A parallel set with no mannitol was maintained as control (no osmotic stress).

\section{Data collection}

Free proline in the leaf tissues was extracted and analyzed as per the method of Bates et al. (1973). Fresh leaf material $(50 \mathrm{mg})$ was ground in liquid nitrogen, mixed with $1 \mathrm{ml}$ of sulfosalicylic acid solution $(3 \% \mathrm{w} / \mathrm{v})$ and filtered. An aliquot of the filtrate was reacted with an equal volume of glacial acetic acid and ninhydrin reagent $(1.25 \mathrm{mg}$ ninhydrin in $30 \mathrm{ml}$ glacial acetic acid and $20 \mathrm{ml}_{6} \mathrm{M} \mathrm{H}_{3} \mathrm{PO}_{4}$ ) and incubated at $95^{\circ} \mathrm{C}$ for $1 \mathrm{~h}$. Then, the mixture was mixed vigorously with $2 \mathrm{ml}$ of toluene. After cooling to $25^{\circ} \mathrm{C}$, the absorbance of the chromophore was measured at $520 \mathrm{~nm}$ on a spectrophotometer (HACH DR/4000; Model 48000, HACH Company, Loveland, Colorado, USA) using L-proline as a standard.

Contents of chlorophyll a $\left(\mathrm{Chl}_{\mathrm{a}}\right)$, chlorophyll b $\left(\mathrm{Chl}_{\mathrm{b}}\right)$ and total chlorophyll (TC) were determined as per the method of Shabala et al. (1998). Leaf material $(100 \mathrm{mg})$ was using an electric homogenizer. The glass vials were sealed with parafilm and kept at $4^{\circ} \mathrm{C}$ for $48 \mathrm{~h}$. The absorbance of the chromophore was measured at 662 and $644 \mathrm{~nm}$ using a UV-visible spectrophotometer.

Chlorophyll fluorescence emission from the leaf adaxial surface was measured using a fluorescence monitoring system (model FMS 2; Hansatech Instruments Ltd., Norfolk, UK) in the pulse amplitude modulation mode (Loggini et al. 1999). Original $\left(\mathrm{F}_{0}\right)$ and maximum $\left(\mathrm{F}_{\mathrm{m}}\right)$ fluorescence yields were measured under weak modulated red light $\left(<0.5 \mu \mathrm{mol} \mathrm{m}^{-2} \mathrm{~s}^{-1}\right)$ with $1.6 \mathrm{~s}$ pulses of saturating light $\left(>6.8 \mu \mathrm{mol} \mathrm{m}^{-2} \mathrm{~s}^{-1}\right.$ $P A R)$. The variable fluorescence yield $\left(\mathrm{F}_{\mathrm{v}}\right)$ was calculated as: $\mathrm{F}_{\mathrm{v}}=\mathrm{F}_{\mathrm{m}}-\mathrm{F}_{0}$. The maximum quantum yield of PSII was determined as $\mathrm{F}_{\mathrm{v}} / \mathrm{F}_{\mathrm{m}}$. The photon yield of PSII $\left(\Phi_{\mathrm{PSII}}\right)$ in the light was calculated as $\Phi_{\text {PSII }}=\left(\mathrm{F}_{\mathrm{m}}{ }^{\prime}-\mathrm{F}_{\mathrm{v}}\right) / \mathrm{F}_{\mathrm{m}}{ }^{\prime}$ after $45 \mathrm{~s}$ of illumination at steady state. In addition, non-photochemical quenching (NPQ) was calculated following the method of Maxwell and Johnson (2000).

Net photosynthetic rate $\left(\mathrm{P}_{\mathrm{n}} ; \mu \mathrm{mol} \mathrm{m}^{-2} \mathrm{~s}^{-1}\right)$ was calculated by comparing the different concentrations of $\mathrm{CO}_{2}$ inside $\left(\mathrm{C}_{\text {in }}\right)$ and outside $\left(\mathrm{C}_{\text {out }}\right)$ the glass vessel containing the sugarcane plantlets. The $\mathrm{CO}_{2}$ concentrations at steady state were measured by a gas chromatograph (GC; Model GC-17A, Shimadzu Co. Ltd., Japan). The $\mathrm{P}_{\mathrm{n}}$ of in vitro cultivated plantlets was calculated as described by Fujiwara et al. (1987).

Data for various growth parameters such as shoot height, root length, fresh weight, dry weight and leaf area of sugarcane plantlets were recorded 14-days after the start of mannitolinduced osmotic stress treatment. Plantlets were dried at $80^{\circ} \mathrm{C}$ in a hot-air oven for $48 \mathrm{~h}$ and their dry weights were recorded. The leaf area was measured using a Root/Leaf Area Meter DT-scan (Delta-Scan Version 2.03, Delta-T Devices, Ltd., Cambridge, UK). Quantification of free proline, photosynthetic pigments, chlorophyll fluorescence, photosynthetic capacity and growth was done following the method given in Cha-um et al. (2009).

\section{Field trial evaluation}

Plantlets of seven sugarcane cultivars were directly transferred to plastic bags containing clay soil $\left(\mathrm{EC}=2.687 \mathrm{dS} \mathrm{m}^{-1} ; \mathrm{pH}=5.5\right.$; organic matter $=10.36 \%$; total $\mathrm{N}=0.17 \%$; total $\mathrm{P}=0.07 \%$; total $\mathrm{K}=1.19 \%$ ) in $50 \%$ shading light intensity in the greenhouse for 1 month (i.e. acclimatization). Irrigation was applied as water spray. Acclimatized plants were directly transplanted into a field $(30 \mathrm{~cm}$ plant to plant and $150 \mathrm{~cm}$ row to row distance) at two sites including well irrigation (control; WW) and rain-fed $\left(554 \mathrm{~mm} \mathrm{year}^{-1}\right)$ water deficit (WD) in Chaiyaphum, Northeast of Thailand (Latitude $16^{\circ} 35^{\prime} \mathrm{N}$ and Longitude $101^{\circ} 55^{\prime} \mathrm{E}$; Fig. 1). In addition, SWC was calculated using the weight fraction: SWC $(\%)=[(\mathrm{FW}-\mathrm{DW}) / \mathrm{DW}] \times 100$, where $\mathrm{FW}$ was the fresh weight of a soil portion of the internal area of each pot and DW was the dry weight of the soil portion after drying in a hot air oven at $85^{\circ} \mathrm{C}$ for 4 days (Coombs et al. 1987). Chemical fertilizer (16:16:16; nitrogen: phosphorus: potassium) was applied three times, i.e., February, May and August at $0.0156 \mathrm{~kg} \mathrm{~m}^{-2}$ prior to stalk harvesting in November 2010. Plant height, stalk weight, number of stalks per plot and total stalk weight per plot were recorded.

\section{Experimental design and statistical analysis}

The experiment was arranged as $7 \times 2$ factorials in a Completely Randomized Block Design (CRBD) with 8 replicates $(n=8)$. The mean values obtained were compared using the Duncan's New Multiple Range Test (DMRT) and analyzed with the 
SPSS software. To classify the sugarcane lines into drought tolerant and sensitive categories, data for proline accumulation, photosynthetic pigments, chlorophyll fluorescence, photosynthetic capacity and growth under osmotic stress were subjected to the Ward's method of Hierarchical cluster analysis using SPSS software.

\section{Results and discussion}

\section{Growth performance of sugarcane cultivars}

Mannitol-induced water stress caused a marked decrease in growth attributes such as shoot length, fresh weight, dry weight and leaf area in all the seven sugarcane cultivars (Table 1). However, the level of reduction varied in different genotypes. Cultivars LK92-11, K97-32, and K95-84 produced higher shoot fresh and dry weight than the other cultivars under osmotic stress conditions. Likewise, root length in decreased (20.97-42.5\% reduction) in all cultivars under osmotic stress and the root length was the lowest in K92-80 (21.15\% reduction) and K97-32 (20.97\% reduction). These observations are paralleled by earlier studies reporting differential response of sugarcane genotypes under drought stress. For example, Wagih et al. (2003) screened 26 sugarcane cultivars for drought tolerance using plant height and biomass as selection criteria. They observed 15.21$33.33 \%, 68.34-81.70 \%$ and $61.89-77.43 \%$ reduction in plant height, fresh weight and dry weight, respectively, in 26 sugarcane cultivars (Wagih et al. 2003). Smit and Singels (2006) used leaf area reduction (as Leaf area index, LAI) as a potential indicator for drought tolerance in sugarcane cultivars. In sugarcane cultivar "NCo376" LAI was maintained during early drought stress (i.e. 28 days after drying); however, it dropped under dry conditions for long periods. In contrast, LAI in cultivar "N22" decreased quickly in early drought condition (14 days after drying) (Smit and Singels 2006).

\section{Photosynthetic pigments}

Chlorophyll $a\left(\mathrm{Chl}_{a}\right)$ content decreased in sugarcane cultivars, K88-92, K92-80, LK92-11, K95-84 and UT94-2483, when subjected to osmotic stress, whereas it remained unchanged in K84-200 and K97-32 (Table 2). In general, the degradation of $\mathrm{Chl}_{a}$ in ranged from $13.28 \%$ (in K84-200) to $41.68 \%$ (in K92-80) over that in the control. Likewise, chlorophyll $b\left(\mathrm{Chl}_{b}\right)$ content declined in the leaf tissues of K88-92 (46.85\%), K9732 (27.31\%), LK92-11 (35.58\%) and UT-94-2483 (54.05\%), while it remained unaffected in K84-200 (0\%) under mannitol-induced stress. The reduction in total chlorophyll (TC) in followed a trend parallel to that of $\mathrm{Chl}_{a}$ and $\mathrm{Chl}_{b}$ (Table 2). TC content declined in the range of $6.57 \%$ (K84-200) to $39.61 \%$ (UT-94-2-483). The ratio of $\mathrm{Chl}_{a}$ to $\mathrm{Chl}_{b}$ was enhanced in the cultivars K88-92, K97-32, LK92-11 and UT-94-2-483, whereas a decline was observed in K84-200, K92-80 and K95-84 under $200 \mathrm{mM}$ mannitol-induced stress (Table 2). In general, photosynthetic pigments in osmotically stressed plants are considered as one of the most sensitive parameters for assessing crop salt tolerance, especially in sensitive genotypes (Cha-um et al. 2012). For example, a greater decline in $\mathrm{Chl}_{a}$ content was recorded in drought sensitive sugarcane cultivar "Cadmus" compared to that in in drought tolerant 'Q77N1232', when exposed to drought conditions (Wagih et al. 2004). Similarly, a decline in TC content was seen in drought susceptible genotypes i.e. CP92-675, H99-295, and TCP02-4624, of sugarcane, whereas there was no change in TC content in droughttolerant cultivars, - HOCP85-845, TCP02-4587, TCP024620, and US01-40, (Silva et al. 2007). In cultivar "K84200", $\mathrm{Chl}_{b}$ content in osmotic stressed leaf tissues was high. Likewise, in spinach, chlorophyll content per fresh weight of leaf increased when there was a reduced relative water content (Gupta and Berkowitz 1988). In of late, studies have reported no change in TC content in drought tolerant cultivars (HOCP01-523, TCP89-3505, and RB867515) of sugarcane under osmotic stress (Silva et al. 2011; da Silva et al. 2012). Chlorophyll degradation in sugarcane exposed to osmotic stress may have a negative effect on photosynthetic capacity, especially in the PSII light harvesting complex (Cha-um and Kirdmanee 2008).

\section{Chlorophyll fluorescence and photosynthetic capacity}

Maximum quantum yield of PSII $\left(\mathrm{F}_{\mathrm{v}} / \mathrm{F}_{\mathrm{m}}\right)$ decreased by $21.18 \%$ in the sugarcane cultivar "K95-84" under osmotic stress (Table 3 ), whereas the $\mathrm{F}_{\mathrm{v}} / \mathrm{F}_{\mathrm{m}}$ in other cultivars did not change (1.19-10.71\%). On the other hand, photon yield of PSII $\left(\Phi_{\text {PSII }}\right)$ decreased in the range of $8.77 \%$ (K97-32) to $26.32 \%$ (K88-92). A positive relationship was observed between $\mathrm{F}_{\mathrm{v}} / \mathrm{F}_{\mathrm{m}}$ and $\Phi_{\text {PSII }}$ (Fig. 2A). In contrast, non-photochemical quenching (NPQ) was inhibited and it correlated positively with proline content (Fig. 2B). The $\Phi_{\text {PSII }}$ in sugarcane plantlets declined when exposed to mannitol-induced osmotic stress (Table 3), and it correlated positively with reduced net photosynthetic rate $\left(\mathrm{P}_{\mathrm{n}}\right)$ (Fig. 3A). A sharp water stress-induced decline in $\mathrm{P}_{\mathrm{n}}$ ranging from $42.7 \%$ (K88-92) to $80.0 \%$ (LK92-11) was observed under osmotic stress (Table 3), and it may have been one of the major factors of reducing plant dry weight (Fig. 3B). A decline in chlorophyll fluorescence in water stressed plants is a general response of many plant species. The observations made in the present study are corroborated by earlier findings. For example, $F_{v} / F_{m}$ remained unchanged in the drought-tolerant genotypes (HOCP85-845, TCP02-4587, TCP02-4620 and US0140) under drought conditions, whereas it declined significantly in susceptible genotypes (CP72-1210, CP92-675 and H99-295) (Silva et al. 2007). Likewise, a 

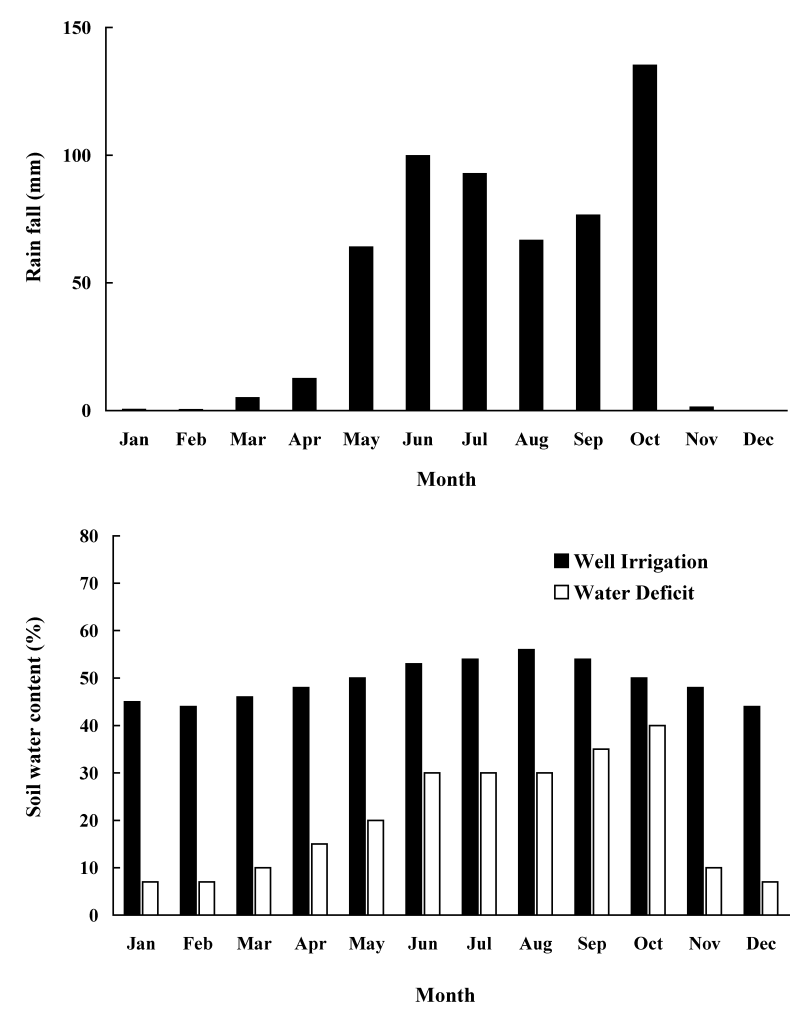

Figure 1. Monthly annual precipitation (A) and soil water content (B) of the field with well irrigation (WW) and without irrigation (WD) at Chaiyaphum province, Northeast of Thailand in year 2010.

decline was observed in $\mathrm{F}_{\mathrm{v}} / \mathrm{F}_{\mathrm{m}}$ in the drought sensitive genotypes, viz., SP86-155, SP90-1638, TCP87-3388,
HOCP93-776 and RB92579 under simulated drought stress; and it may one of the major causes of reduction in $\mathrm{P}_{\mathrm{n}}$ under osmotic stress (Silva et al. 2007; Rodrigues et al. 2009; da Graça et al. 2010; Silva et al. 2011; da Silva et al. 2012). The efficiency of photochemical quenching in PSII relates to high value of $\mathrm{F}_{\mathrm{v}} / \mathrm{F}_{\mathrm{m}}$ and $\Phi_{\mathrm{PSII}}$ and it paralleled the observation made in water deficit tolerant genotypes (HOCP85-845, TCP02-4587, TCP02-4620 and US01-40) (Silva et al. 2007). In $\mathrm{C}_{4}$ grasses, non-stomatal limitation in photosynthesis, including $\mathrm{F}_{\mathrm{v}} / \mathrm{F}_{\mathrm{m}}$ and $\Phi_{\text {PSII }}$, has been reported as a major barrier to growth under drought stress (Ghannoum et al. 2003). Aditionally, low NPQ has been reported to provide protection against photo-oxidative damage (Müller et al. 2001; Omasa and Takayama 2003). In a recent study, a reduction in $\mathrm{F}_{\mathrm{v}} /$ $\mathrm{F}_{\mathrm{m}}$ and $\Phi_{\text {PSII }}$ in some sugarcane cultivars was observed, and it resulted in reduced $\mathrm{P}_{\mathrm{n}}$ (Rodrigues et al. 2009; da Silva et al. 2012). Previously, $P_{n}$ has been demonstrated to be a very sensitive parameter for the classification of sugarcane germplasm for drought tolerance (de Silva and de Costa 2009; da Silva et al. 2012) and it has been found to hold good in the present study and useful in screening the sugarcane cultivars for drought tolerance.

\section{Proline content}

Proline content in the leaf tissues of water-deficit stressed plantlets increased over that in the control. However, it remained unchanged in K97-32 and K92-80. In K9280, K97-32 and K95-84 proline content was very low $\left(<1.0 \mu \mathrm{mol} \mathrm{g}^{-1} \mathrm{FW}\right)$ when plantlets were subjected to

Table 1. Shoot height (SH), root length (RL), fresh weight (FW), dry weight (DW) and leaf area (LA) in sugarcane cultivars grown under 0 (control) and $200 \mathrm{mM}$ mannitol (osmotic stress) for 14 days. Percent reduction in each growth attributes of osmotic stressed plantlets of each cultivar is presented in each column.

\begin{tabular}{|c|c|c|c|c|c|c|}
\hline Cultivars & Mannitol (mM) & $\mathrm{SH}(\mathrm{cm})$ & $\mathrm{RL}(\mathrm{cm})$ & FW (mg) & DW (mg) & LA $\left(\mathrm{cm}^{2}\right)$ \\
\hline \multirow[t]{3}{*}{ K84-200 } & 0 & $24.3^{\mathrm{ab}}$ & $7.6^{\mathrm{b}}$ & $670^{\mathrm{bc}}$ & $103^{\text {cde }}$ & $17.8^{\mathrm{b}}$ \\
\hline & 200 & $12.9^{\mathrm{f}}$ & $5.1^{\mathrm{de}}$ & $295^{\mathrm{fg}}$ & $61^{\mathrm{fg}}$ & $11.2^{\mathrm{de}}$ \\
\hline & & $(46.91 \%)$ & $(32.90 \%)$ & (55.97\%) & $(40.78 \%)$ & $(37.08 \%)$ \\
\hline \multirow[t]{3}{*}{ K88-92 } & 0 & $21.0^{\mathrm{bc}}$ & $4.0^{\mathrm{f}}$ & $568^{\mathrm{de}}$ & $77^{\mathrm{de}}$ & $18.9^{\mathrm{b}}$ \\
\hline & 200 & $15.3^{\text {def }}$ & $2.3^{\mathrm{g}}$ & $225^{\mathrm{g}}$ & $35^{\mathrm{gh}}$ & $9.7^{\mathrm{de}}$ \\
\hline & & $(27.14 \%)$ & $(42.50 \%)$ & $(60.39 \%)$ & $(54.55 \%)$ & $(48.68 \%)$ \\
\hline \multirow[t]{3}{*}{ K92-80 } & 0 & $24.2^{\mathrm{ab}}$ & $5.2^{\mathrm{de}}$ & $801^{\mathrm{bc}}$ & $109^{b c}$ & $24.4^{\mathrm{a}}$ \\
\hline & 200 & $18.5^{\text {cde }}$ & $4.1^{\mathrm{ef}}$ & $198^{g}$ & $22^{\mathrm{h}}$ & $15.3^{\mathrm{bc}}$ \\
\hline & & $(23.55 \%)$ & $(21.15 \%)$ & $(75.28 \%)$ & $(79.82 \%)$ & $(37.30 \%)$ \\
\hline \multirow[t]{3}{*}{ K95-84 } & 0 & $25.4^{\mathrm{ab}}$ & $5.6^{\mathrm{cd}}$ & $867^{\mathrm{b}}$ & $127^{\mathrm{b}}$ & $23.7^{\mathrm{a}}$ \\
\hline & 200 & $14.9^{\mathrm{ef}}$ & $3.8^{\mathrm{f}}$ & $459^{\mathrm{ef}}$ & $71^{\text {ef }}$ & $6.7^{\mathrm{e}}$ \\
\hline & & $(41.34 \%)$ & $(32.14 \%)$ & $(47.06 \%)$ & $(44.10 \%)$ & $(71.73 \%)$ \\
\hline \multirow[t]{3}{*}{ K97-32 } & 0 & $26.3^{\mathrm{a}}$ & $6.2^{\mathrm{cd}}$ & $1126^{\mathrm{a}}$ & $131^{\mathrm{b}}$ & $26.8^{\mathrm{a}}$ \\
\hline & 200 & $20.3^{b c}$ & $4.9^{\mathrm{de}}$ & $602^{\text {cd }}$ & $85^{\mathrm{de}}$ & $10.9^{\mathrm{de}}$ \\
\hline & & $(22.81 \%)$ & $(20.97 \%)$ & $(46.54 \%)$ & $(35.12 \%)$ & $(59.33 \%)$ \\
\hline \multirow[t]{3}{*}{ LK92-11 } & 0 & $29.6^{\mathrm{a}}$ & $9.8^{\mathrm{a}}$ & $798^{\mathrm{bc}}$ & $113^{\mathrm{bc}}$ & $23.2^{\mathrm{a}}$ \\
\hline & 200 & $15.3^{\mathrm{def}}$ & $6.7^{\mathrm{bc}}$ & $515^{\mathrm{de}}$ & $74^{\mathrm{ef}}$ & $13.0^{\mathrm{cd}}$ \\
\hline & & $(48.31 \%)$ & $(31.63 \%)$ & $(35.46 \%)$ & $(34.51 \%)$ & $(43.97 \%)$ \\
\hline \multirow[t]{3}{*}{ UT-94-2-483 } & 0 & $27.7^{\mathrm{a}}$ & $7.8^{\mathrm{b}}$ & $815^{\mathrm{bc}}$ & $170^{\mathrm{a}}$ & $25.4^{\mathrm{a}}$ \\
\hline & 200 & $16.8^{\text {def }}$ & $5.5^{\mathrm{cd}}$ & $376^{\mathrm{fg}}$ & $65^{\mathrm{fg}}$ & $8.2^{\mathrm{e}}$ \\
\hline & & $(39.35 \%)$ & $(29.49 \%)$ & $(53.87 \%)$ & $(61.77 \%)$ & $(67.72 \%)$ \\
\hline
\end{tabular}

Different letters in each column show significant difference at $p \leq 0.01$ by Duncan's New Multiple Range Test (DMRT). 
Table 2. Chlorophyll $a\left(\mathrm{Chl}_{a}\right)$, chlorophyll $b\left(\mathrm{Chl}_{b}\right)$, total chlorophyll (TC) and $\mathrm{Chl}_{a}: \mathrm{Chl}_{b}$ ratio in sugarcane cultivars grown under 0 (control) and $200 \mathrm{mM}$ mannitol (osmotic stress) for 14 days. Percent reduction in photosynthetic pigments of osmotic stressed plantlets in each cultivar is presented in each column.

\begin{tabular}{|c|c|c|c|c|c|}
\hline Cultivars & Mannitol (mM) & $\mathrm{Chl}_{\mathrm{a}}\left(\mu \mathrm{gg}^{-1} \mathrm{FW}\right)$ & $\mathrm{Chl}_{\mathrm{b}}\left(\mu \mathrm{gg}^{-1} \mathrm{FW}\right)$ & $\mathrm{TC}\left(\mu \mathrm{gg}^{-1} \mathrm{FW}\right)$ & $\mathrm{Chl}_{\mathrm{a}}: \mathrm{Chl}_{\mathrm{b}}$ \\
\hline \multirow[t]{2}{*}{ K84-200 } & 0 & $103.9^{\mathrm{de}}$ & $63.6^{\mathrm{cd}}$ & $167.5^{\mathrm{bc}}$ & $1.66^{\mathrm{bc}}$ \\
\hline & 200 & $\begin{array}{l}90.1^{\mathrm{e}} \\
(13.28 \%)\end{array}$ & $\begin{array}{l}66.4^{\mathrm{cd}} \\
(0 \%)\end{array}$ & $\begin{array}{l}156.5^{\mathrm{bc}} \\
(6.57 \%)\end{array}$ & $1.35^{\mathrm{bc}}$ \\
\hline \multirow[t]{2}{*}{ K88-92 } & 0 & $157.1^{\mathrm{b}}$ & $125.5^{\mathrm{a}}$ & $286.6^{\mathrm{a}}$ & $1.32^{\mathrm{bc}}$ \\
\hline & 200 & $\begin{array}{l}107.8^{\mathrm{de}} \\
(31.38 \%)\end{array}$ & $\begin{array}{l}66.7^{\mathrm{cd}} \\
(46.85 \%)\end{array}$ & $\begin{array}{l}174.5^{\mathrm{b}} \\
(39.11 \%)\end{array}$ & $1.62^{\mathrm{bc}}$ \\
\hline \multirow[t]{2}{*}{ K92-80 } & 0 & $91.9^{\mathrm{e}}$ & $64.5^{\mathrm{cd}}$ & $156.4^{\mathrm{bc}}$ & $1.44^{\mathrm{bc}}$ \\
\hline & 200 & $\begin{array}{l}53.6^{\mathrm{f}} \\
(41.68 \%)\end{array}$ & $\begin{array}{c}47.8^{\mathrm{d}} \\
(25.89 \%)\end{array}$ & $\begin{array}{l}101.4^{\mathrm{c}} \\
(35.17 \%)\end{array}$ & $1.12^{\mathrm{c}}$ \\
\hline \multirow[t]{2}{*}{ K95-84 } & 0 & $122.3^{\mathrm{de}}$ & $73.7^{\mathrm{cd}}$ & $196.0^{\mathrm{b}}$ & $1.75^{\mathrm{bc}}$ \\
\hline & 200 & $\begin{array}{l}93.1^{\mathrm{e}} \\
(23.88 \%)\end{array}$ & $\begin{array}{l}58.2^{\mathrm{d}} \\
(21.03 \%)\end{array}$ & $\begin{array}{l}151.3^{\mathrm{bc}} \\
(22.81 \%)\end{array}$ & $1.61^{\mathrm{bc}}$ \\
\hline \multirow[t]{2}{*}{ K97-32 } & 0 & $119.3^{\mathrm{de}}$ & $80.2^{\mathrm{bc}}$ & $199.5^{\mathrm{b}}$ & $1.58^{\mathrm{bc}}$ \\
\hline & 200 & $\begin{array}{l}93.8^{\mathrm{e}} \\
(21.38 \%)\end{array}$ & $\begin{array}{l}58.3^{\mathrm{d}} \\
(27.31 \%)\end{array}$ & $\begin{array}{l}152.1^{\mathrm{bc}} \\
(23.76 \%)\end{array}$ & $1.61^{\mathrm{bc}}$ \\
\hline \multirow[t]{2}{*}{ LK92-11 } & 0 & $191.4^{\mathrm{a}}$ & $100.9^{\mathrm{ab}}$ & $292.3^{\mathrm{a}}$ & $1.95^{\mathrm{b}}$ \\
\hline & 200 & $\begin{array}{l}146.3^{\mathrm{bc}} \\
(23.56 \%)\end{array}$ & $\begin{array}{l}65.0^{\text {cd }} \\
(35.58 \%)\end{array}$ & $\begin{array}{l}211.3^{\mathrm{b}} \\
(27.71 \%)\end{array}$ & $2.49^{\mathrm{a}}$ \\
\hline \multirow{2}{*}{ UT-94-2-483 } & 0 & $197.4^{\mathrm{a}}$ & $114.9^{\mathrm{a}}$ & $312.3^{\mathrm{a}}$ & $1.73^{\mathrm{bc}}$ \\
\hline & 200 & $\begin{array}{l}135.8^{\mathrm{cd}} \\
(31.21 \%)\end{array}$ & $\begin{array}{l}52.8^{\mathrm{d}} \\
(54.05 \%)\end{array}$ & $\begin{array}{l}188.6^{\mathrm{b}} \\
(39.61 \%)\end{array}$ & $2.65^{\mathrm{a}}$ \\
\hline
\end{tabular}

Different letters in each column show significant difference at $p \leq 0.01$ by Duncan's New Multiple Range Test (DMRT).
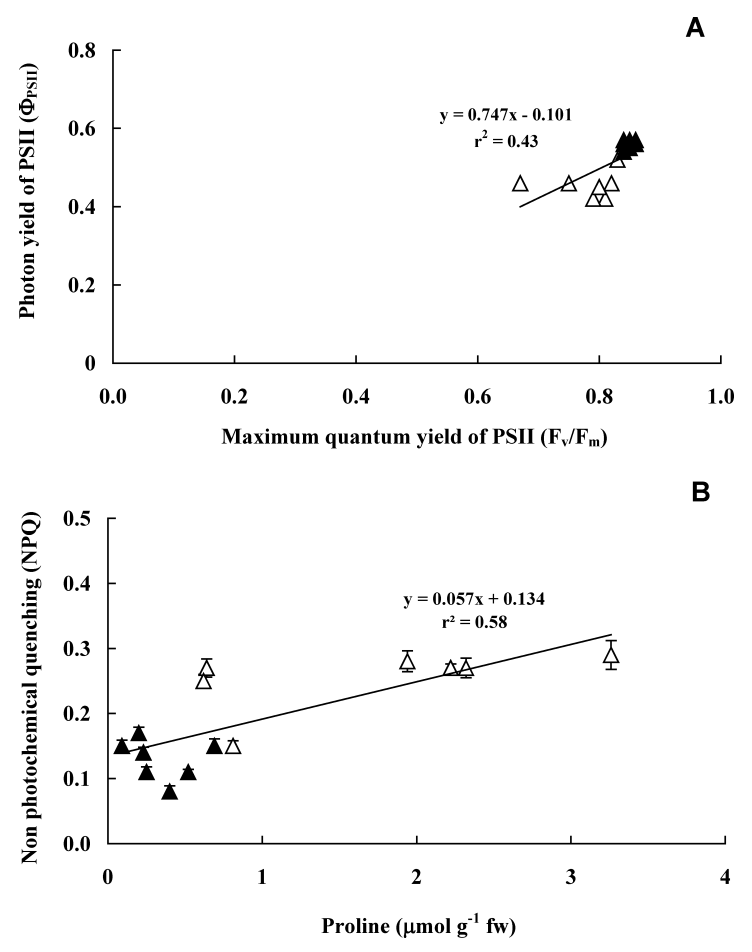

Figure 2. Relationships between maximum quantum yield of PSII $\left(\mathrm{F}_{\mathrm{v}} / \mathrm{F}_{\mathrm{m}}\right)$ and photon yield of PSII $\left(\Phi_{\mathrm{PSII}}\right)(\mathrm{A})$, proline and nonphotochemical quenching (NPQ) (B) in sugarcane cultivars grown under 0 (control; dark symbol) and $200 \mathrm{mM}$ mannitol (osmotic stress; light symbol) for 14 days. Error bars represent \pm SE.

$200 \mathrm{mM}$ mannitol-induced osmotic stress (Fig. 2B). Proline accumulation is a good indicator of drought tolerant genotypes in sugarcane (Errabii et al. 2006;
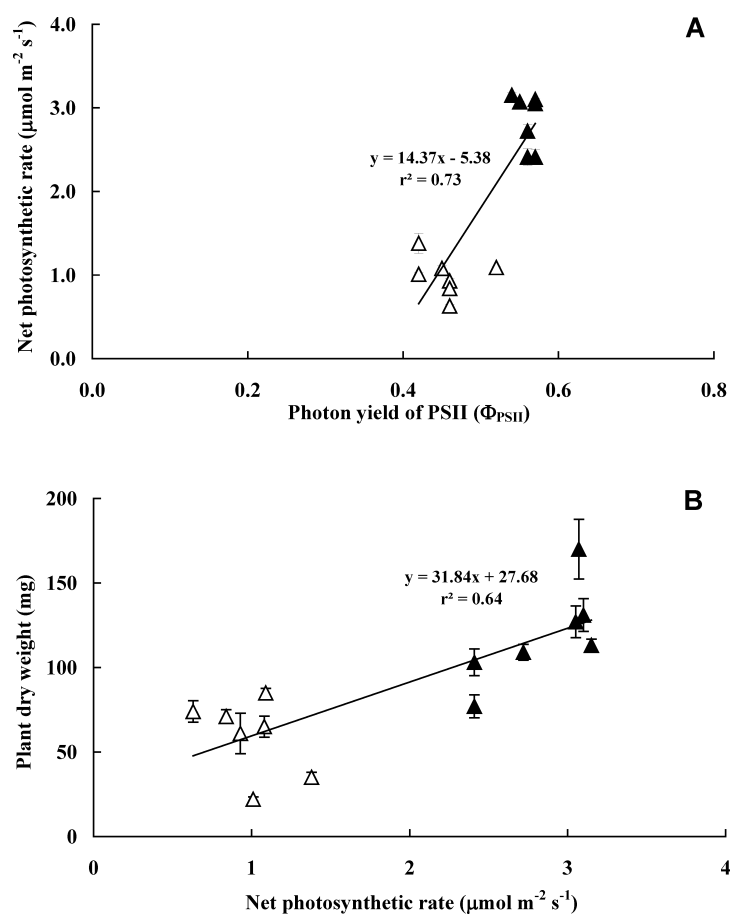

Figure 3. Relationships between photon yield of PSII $\left(\Phi_{\text {PSII }}\right)$ and net photosynthetic rate $\left(\mathrm{P}_{\mathrm{n}}\right)(\mathrm{A}), \mathrm{P}_{\mathrm{n}}$ and plant dry weight $(\mathrm{B})$ in sugarcane cultivars grown under 0 (control; dark symbol) and $200 \mathrm{mM}$ mannitol (osmotic stress; light symbol) for 14 days. Error bars represent \pm SE.

Queiroz et al. 2011). Previously, enhanced proline content has been observed in sugarcane plantlets of $\mathrm{cv}$. K84-200 under mannitol-induced osmotic stress (Chaum and Kirdmanee 2008). Likewise, proline content 
Table 3. Maximum quantum yield of PSII $\left(\mathrm{F}_{\mathrm{v}} / \mathrm{F}_{\mathrm{m}}\right)$, photon yield of PSII $\left(\Phi_{\mathrm{PSII}}\right)$, non- photochemical quenching (NPQ) and net photosynthetic rate $\left(\mathrm{P}_{\mathrm{n}}\right)$ in sugarcane cultivars grown under 0 (control) and $200 \mathrm{mM}$ mannitol (osmotic stress) for 14 days. Percent reduction in photosynthetic abilities of osmotic stressed plantlets in each cultivar is presented in each column.

\begin{tabular}{|c|c|c|c|c|c|}
\hline Cultivars & Mannitol (mM) & $\mathrm{F}_{\mathrm{v}} / \mathrm{F}_{\mathrm{m}}$ & $\Phi_{\text {PSII }}$ & NPQ & $\mathrm{P}_{\mathrm{n}}\left(\mu \mathrm{mol} \mathrm{m}^{-2} \mathrm{~s}^{-1}\right)$ \\
\hline \multirow[t]{3}{*}{ K84-200 } & 0 & $0.86^{\mathrm{a}}$ & $0.56^{\mathrm{ab}}$ & $0.14^{\mathrm{cd}}$ & $2.41^{\mathrm{c}}$ \\
\hline & 200 & $0.82^{\mathrm{ab}}$ & $0.46^{\mathrm{c}}$ & $0.27^{\mathrm{ab}}$ & $0.93^{\text {ef }}$ \\
\hline & & $(4.65 \%)$ & $(17.86 \%)$ & (1.93 folds) & $(61.41 \%)$ \\
\hline \multirow[t]{3}{*}{ K88-92 } & 0 & $0.86^{\mathrm{a}}$ & $0.57^{\mathrm{a}}$ & $0.17^{\mathrm{c}}$ & $2.41^{\mathrm{c}}$ \\
\hline & 200 & $0.81^{\mathrm{bc}}$ & $0.42^{\mathrm{c}}$ & $0.29^{\mathrm{a}}$ & $1.38^{\mathrm{d}}$ \\
\hline & & $(5.81 \%)$ & $(26.32 \%)$ & (1.71 folds) & $(42.74 \%)$ \\
\hline \multirow[t]{3}{*}{ K92-80 } & 0 & $0.84^{\mathrm{ab}}$ & $0.56^{\mathrm{ab}}$ & $0.15^{\text {cd }}$ & $2.72^{\mathrm{b}}$ \\
\hline & 200 & $0.79^{\mathrm{cd}}$ & $0.42^{\mathrm{c}}$ & $0.27^{\mathrm{ab}}$ & $1.01^{\mathrm{ef}}$ \\
\hline & & $(5.95 \%)$ & $(25.0 \%)$ & (1.80 folds) & $(62.87 \%)$ \\
\hline \multirow[t]{3}{*}{ K95-84 } & 0 & $0.85^{\mathrm{ab}}$ & $0.57^{\mathrm{a}}$ & $0.15^{\mathrm{cd}}$ & $3.05^{\mathrm{a}}$ \\
\hline & 200 & $0.67^{\mathrm{e}}$ & $0.46^{\mathrm{c}}$ & $0.25^{\mathrm{b}}$ & $0.84^{\mathrm{f}}$ \\
\hline & & $(21.18 \%)$ & $(19.30 \%)$ & (1.67 folds) & $(72.46 \%)$ \\
\hline \multirow[t]{3}{*}{ K97-32 } & 0 & $0.84^{\mathrm{ab}}$ & $0.57^{\mathrm{a}}$ & $0.11^{\mathrm{de}}$ & $3.10^{\mathrm{a}}$ \\
\hline & 200 & $0.83^{\mathrm{bc}}$ & $0.52^{\mathrm{b}}$ & $0.15^{\mathrm{cd}}$ & $1.09^{\mathrm{e}}$ \\
\hline & & $(1.19 \%)$ & $(8.77 \%)$ & (1.36 folds) & $(64.84 \%)$ \\
\hline \multirow[t]{3}{*}{ LK92-11 } & 0 & $0.84^{\mathrm{ab}}$ & $0.54^{\mathrm{ab}}$ & $0.11^{\mathrm{de}}$ & $3.15^{\mathrm{a}}$ \\
\hline & 200 & $0.75^{\mathrm{d}}$ & $0.46^{\mathrm{c}}$ & $0.27^{\mathrm{ab}}$ & $0.63^{\mathrm{g}}$ \\
\hline & & $(10.71 \%)$ & $(14.81 \%)$ & (2.45 folds) & $(80.0 \%)$ \\
\hline \multirow{3}{*}{ UT-94-2-483 } & 0 & $0.85^{\mathrm{ab}}$ & $0.55^{\mathrm{ab}}$ & $0.08^{\mathrm{e}}$ & $3.07^{\mathrm{a}}$ \\
\hline & 200 & $0.80^{\mathrm{bc}}$ & $0.45^{\mathrm{c}}$ & $0.28^{\mathrm{ab}}$ & $1.08^{\mathrm{e}}$ \\
\hline & & $(5.88 \%)$ & $(18.18 \%)$ & (3.5 folds) & $(64.82 \%)$ \\
\hline
\end{tabular}

Different letters in each column show significant difference at $p \leq 0.01$ by Duncan's New Multiple Range Test (DMRT).

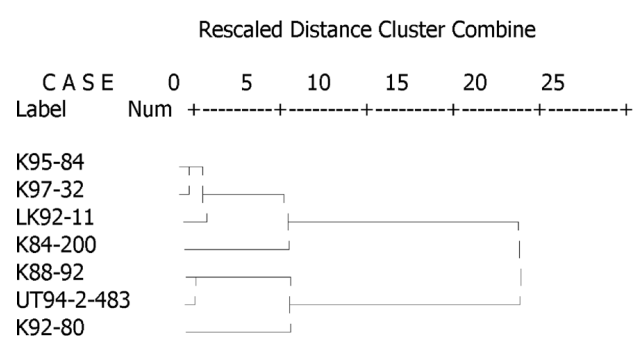

Rescaled Distance Cluster Combine

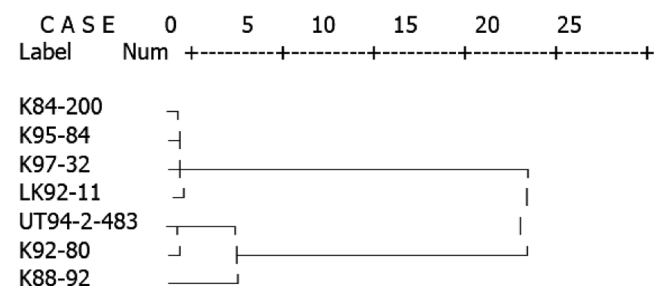

Figure 4. Ward's dendrogram for sugarcane cultivars to classify as (A) water-deficit sensitive, K88-92, K92-80 and UT94-2-483, and water-deficit tolerant, K84-200, K95-84, K97-32 and LK92-11, using proline accumulation, pigment content, chlorophyll fluorescence, net photosynthetic rate, and growth characteristics of in vitro classification as well as (B) water-deficit sensitive, K88-92, K92-80 and UT94-2-483, and water-deficit tolerant, K84-200, K95-84, K97-32 and LK92-11, using plant height, stalk weight, number of stalk per plot, and total stalk weight of field trial evaluation.

was greater in drought tolerant sugarcane cultivars (Q77N1232, N11, CP59-73 and ICA91-5155) than that in drought susceptible cultivars-Cadmus (Wagih et al.

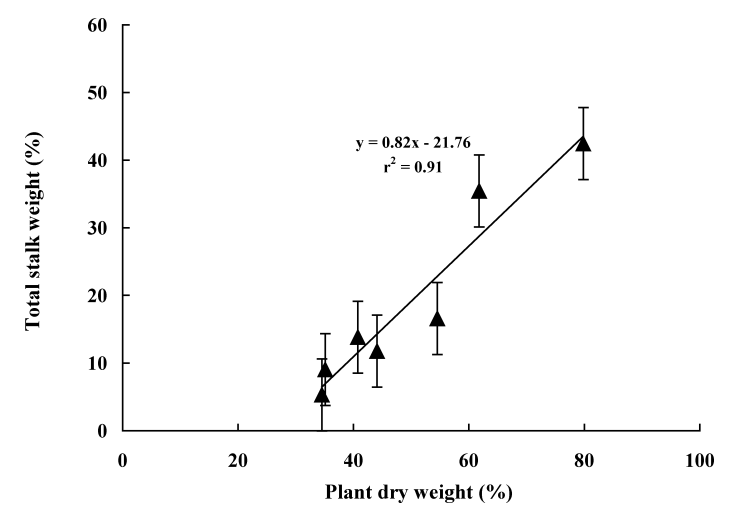

Figure 5. Relationships between plant dry weight (\%) in vitro and total stalk weight (\%) in a field trial of sugarcane cultivars. Error bars represent \pm SE.

2004), N12 (Rutherford 1989), R570 (Errabii et al. 2006), and ICA91-2195 (Queiroz et al. 2011) grown under osmotic stress. In fact, proline accumulation is a good indicator of identification of drought tolerant genotypes in sugarcane (Errabii et al. 2006; Queiroz et al. 2011).

\section{Multivariate cluster analysis}

Data for proline accumulation, photosynthetic pigments, chlorophyll fluorescence, net photosynthetic rate, and growth performance of the sugarcane cultivars were subjected to the Ward's cluster analysis. From this analysis it was possible to classify K88-92, K92-80 and UT94-2-483 as water-deficit sensitive and K84-200, K9584, K97-32 and LK92-11 as water-deficit tolerant (Fig. 4A). Previously, a single parameter including lowest 
Table 4. Plant height (PH), single stalk weight (SW), number of stalk per plot (NS) and total stalk weight per plot (TW) in sugarcane cultivars grown under well irrigation (WW) and rain fed water deficit stress (WD) in the field trial prior to harvesting period (10 months). Percent reduction in each growth and yield attribute of water deficit stressed plants in each cultivar is presented in each column.

\begin{tabular}{|c|c|c|c|c|c|}
\hline Cultivars & Water stress & $\mathrm{PH}(\mathrm{cm})$ & SW $\left(\mathrm{kg} \mathrm{stalk}^{-1}\right)$ & NS & TW $\left(\right.$ kg plot $\left.^{-1}\right)$ \\
\hline \multirow[t]{2}{*}{ K84-200 } & WW & $261^{\mathrm{a}}$ & $1.88^{\mathrm{a}}$ & $84.5^{\mathrm{a}}$ & $156^{\mathrm{a}}$ \\
\hline & WD & $\begin{array}{l}259^{\mathrm{a}} \\
(0.77 \%)\end{array}$ & $\begin{array}{c}1.62^{\mathrm{ab}} \\
(13.83 \%)\end{array}$ & $\begin{array}{l}84.0^{\mathrm{a}} \\
(0.59 \%)\end{array}$ & $\begin{array}{l}148^{\mathrm{a}} \\
(5.43 \%)\end{array}$ \\
\hline \multirow[t]{2}{*}{ K88-92 } & WW & $219^{\mathrm{b}}$ & $1.87^{\mathrm{a}}$ & $74.0^{\mathrm{b}}$ & $103^{\mathrm{bc}}$ \\
\hline & WD & $\begin{array}{l}197^{\mathrm{bc}} \\
(10.05 \%)\end{array}$ & $\begin{array}{c}1.56^{\mathrm{ab}} \\
(16.58 \%)\end{array}$ & $\begin{array}{l}58.8^{\mathrm{de}} \\
(20.54 \%)\end{array}$ & $\begin{array}{l}68^{\mathrm{d}} \\
(34.21 \%)\end{array}$ \\
\hline \multirow[t]{2}{*}{ K92-80 } & WW & $225^{\mathrm{b}}$ & $1.72^{\mathrm{a}}$ & $68.3^{\mathrm{c}}$ & $117^{\mathrm{b}}$ \\
\hline & WD & $\begin{array}{l}160^{c} \\
(29.01 \%)\end{array}$ & $\begin{array}{c}0.99^{\mathrm{c}} \\
(42.44 \%)\end{array}$ & $\begin{array}{l}44.5^{\mathrm{e}} \\
(34.85 \%)\end{array}$ & $\begin{array}{l}45^{\mathrm{e}} \\
(61.72 \%)\end{array}$ \\
\hline \multirow[t]{2}{*}{ K95-84 } & WW & $229^{\mathrm{b}}$ & $1.70^{\mathrm{a}}$ & $75.0^{\mathrm{b}}$ & $128^{\mathrm{ab}}$ \\
\hline & WD & $\begin{array}{l}225^{\mathrm{b}} \\
(1.88 \%)\end{array}$ & $\begin{array}{c}1.50^{\mathrm{ab}} \\
(11.77 \%)\end{array}$ & $\begin{array}{l}72.5^{\mathrm{bc}} \\
(3.33 \%)\end{array}$ & $\begin{array}{l}116^{\mathrm{b}} \\
(8.78 \%)\end{array}$ \\
\hline \multirow[t]{2}{*}{ K97-32 } & WW & $221^{\mathrm{b}}$ & $1.44^{\mathrm{b}}$ & $71.5^{b c}$ & $115^{\mathrm{b}}$ \\
\hline & WD & $\begin{array}{l}218^{\mathrm{b}} \\
(1.45 \%)\end{array}$ & $\begin{array}{l}1.31^{\mathrm{b}} \\
(9.03 \%)\end{array}$ & $\begin{array}{l}66.0^{\mathrm{cd}} \\
(7.69 \%)\end{array}$ & $\begin{array}{l}111^{\mathrm{b}} \\
(3.57 \%)\end{array}$ \\
\hline \multirow[t]{2}{*}{ LK92-11 } & WW & $256^{\mathrm{a}}$ & $1.70^{\mathrm{a}}$ & $61.0^{\mathrm{d}}$ & $101^{\mathrm{bc}}$ \\
\hline & WD & $\begin{array}{l}241^{\mathrm{ab}} \\
(5.66 \%)\end{array}$ & $\begin{array}{c}1.61^{\mathrm{ab}} \\
(5.29 \%)\end{array}$ & $\begin{array}{l}60.0^{\mathrm{d}} \\
(1.64 \%)\end{array}$ & $\begin{array}{l}90^{c} \\
(11.06 \%)\end{array}$ \\
\hline \multirow[t]{2}{*}{ UT-94-2-483 } & WW & $254^{\mathrm{a}}$ & $1.89^{\mathrm{a}}$ & $73.3^{\mathrm{bc}}$ & $142^{\mathrm{a}}$ \\
\hline & WD & $\begin{array}{l}210^{\mathrm{b}} \\
(17.24 \%)\end{array}$ & $\begin{array}{c}1.22^{\mathrm{bc}} \\
(35.45 \%)\end{array}$ & $\begin{array}{l}55.0^{\mathrm{de}} \\
(24.97 \%)\end{array}$ & $\begin{array}{l}68^{\mathrm{d}} \\
(52.42 \%)\end{array}$ \\
\hline
\end{tabular}

Different letters in each column show significant difference at $p \leq 0.01$ by Duncan's New Multiple Range Test (DMRT).

reduction in biomass dry weight has been implemented to classify the drought tolerant genotypes (L6, 20, 9, 26 and 3) of sugarcane with best score (1-3) (Wagih et al. 2003). However, single parameter does not represent overall drought-tolerant defense mechanisms including water relations (Inman-Bamber and Smith 2005; Basra et al. 1999) and osmoregulation (Cha-um and Kidmanee 2008), required to maintain the biochemical, physiological and morphological characters (Silva et al. 2011) and yield attributes (Silva et al. 2007; Silva et al. 2008). Queiroz et al. (2011) employed multivariate analysis of biochemical (proline and trehalose osmolytes) and physiological characters to categorize IAC91-5155 as drought tolerant genotypes of sugarcane (Queiroz et al. 2011). Also, the multivariate parameters have been suggested as effective criteria for drought tolerant selection in sugarcane genotypes (Hemaprabha et al. 2004; Vasantha et al. 2005; Hemaprabha et al. 2006; Silva et al. 2008; Ishaq and Olaoye 2009).

\section{Field trial evaluation}

Yield traits, including single stalk weight, number of stalks per plot and total stalk weight per plot, in each cultivar of sugarcane declined when subjected to rain-fed conditions (water deficit stress), especially in water deficit susceptible cultivars (Table 4). For example, number of stalks per plot of water deficit susceptible cultivars, viz., K88-92, K92-80 and UT-94-2-483 declined by $20.54 \%$, $34.85 \%$ and $24.97 \%$, respectively, when grown in a field trial without irrigation for 10 months. In addition, total stalk weight per plot of water deficit susceptible cultivars, viz., K88-92, K92-80 and UT-94-2-483, decreased by $34.21 \%, 61.72 \%$ and $52.42 \%$, respectively (Table 4 ). In contrast, yield traits in water deficit tolerant cultivars (K84-200, K95-84, K97-32 and LK92-11) were well maintained. From the cluster analysis, it was possible to classify K88-92, K92-80 and UT94-2-483 as water-deficit sensitive and K84-200, K95-84, K97-32 and LK92-11 as water-deficit tolerant genotpyes (Fig. 4B). These findings confirm the observations that data collected from in vitro screening may be used to accurately classify the drought tolerance in sugarcane, when compared to water deficit field trial. The productivity of sugarcane under drought stress conditions could be used as one of the key selection criteria for drought tolerance. In the present study, single stalk weight, number of stalks per plot and total stalk weight per plot of sugarcane cultivars were evaluated as field trial screening criteria. Additionally, a positive relationship was observed between plant dry weight of in vitro grown sugarcane plantlets and total stalk weight (Fig. 5).

These observations are supported by previous findings. For example, single cane weight of 55-high sugared genotypes was reported to decline to $66.10 \%$ when grown under drought stress conditions (Hemaprabha et al. 2004). Moreover, the stalk number and stalk weight of 80 sugarcane genotypes decreased by $15.93 \%$ and $22.47 \%$, respectively, when subjected to limited irrigation (Silva et al. 2008). The survival percentage, single cane weight and sucrose percentage in 16 parental lines of sugarcane 
have been used as criteria for drought resistant breeding program (Hemaprabha et al. 2006).

\section{Acknowledgments}

The authors wish to thank Mitr Phol Co. Ltd. as a major funding source. However, a partial funding to Miss Sukanya Wangmoon through the Young Scientist and Technologist Programme (YSTP), National Science and Technology Development Agency (NSTDA) is also acknowledged with thanks.

\section{References}

Ashraf M (2010) Inducing drought tolerance in plants: recent advances. Biotechnol Adv 28: 169-183

Ashraf M, Akram NA, Al-Qurainy F, Foolad MR (2011) Drought tolerance: Roles of organic osmolytes, growth regulators and mineral nutrients. Adv Agron 111: 249-296

Azevedo RA, Carvalho RF, Cia MA, Gratão PL (2011) Sugarcane under pressure: An overview of biochemical and physiological studies of abiotic stress. Trop Plant Biol 4: 42-51

Basra SMA, Ahmad N, Khaliq A (1999) Water relation studies in water stressed sugarcane (Saccharum officinarum L.). Int J Agric Biol 1: 1-4

Bates LS, Waldren RP, Teare ID (1973) Rapid determination of free proline for water-stress studies. Plant Soil 39: 205-207

Carr MK, Knox JW (2011) The water relations and irrigation requirements of sugar cane (Saccharum officinarum): A review. Exp Agric 47: 1-25

Cha-um S, Boriboonkaset T, Picakum A, Kirdmanee C (2009) Multivariate physiological indices for salt tolerance classification in indica rice (Oryza sativa L. ssp. indica). Gen Appl Plant Physiol 35: $75-87$

Cha-um S, Kirdmanee C (2008) Effect of osmotic stress on proline accumulation, photosynthetic abilities and growth of sugarcane plantlets (Saccharum officinarum L.). Pak J Bot 40: 2541-2552

Cha-um S, Mosaleeyanon K, Kirdmanee C, Supaibulwatana K (2003) A more efficient transplanting system for Thai neem (Azadirachta siamensis Val.) by reducing relative humidity. Sci Asia 29: 189-196

Coombs J, Hall DO, Long SP, Scurlock JMO(1987) Techniques in Bioproductivity and Photosynthesis. Pergamon Oxford

da Graça JP, Rodrigues FA, Farias JRB, de Oliveira CN, HoffmannCampo CB, Zingaretti SM (2010) Physiological parameters in sugarcane cultivars submitted to water deficit. Braz J Plant Physiol 22: 189-197

da Silva PP, Soares L, da Costa JG, Viana LS, de Andrade JCF, Gonçalves ER, dos Santos JM, Barbosa GVS, Nascimento VX, Todaro AR, Riffel A, Grossi-de-Sa MF, Barbosa MHP, Sant'Ana AEG, Neto CER (2012) Part analysis for selection of drought tolerant sugarcane genotypes through physiological components. Ind Crops Prod 37: 11-19

de Silva ALC, de Costa WAJM (2009) Varietal variation in stomatal conductance, transpiration and photosynthesis of commercial sugarcane varieties under two contrasting water regimes. Trop Agric Res Ext 12: 97-102

Errabii T, Gandonou CB, Essalmani H, Abrini J, Idaomar M, SkaliSenhaji N (2006) Growth, proline and ion accumulation in sugarcane callus cultures under drought-induced osmotic stress ant its subsequent relief. Afr J Biotechnol 5: 1488-1493

Fujiwara K, Kozai T, Watanabe L (1987) Fundamental studies on environment in plant tissue culture vessel. (3) Measurement of carbon dioxide gas concentration in closed vessels containing tissue cultured plantlets and estimates of net photosynthetic rates of the plantlets. J Agric Method 43: 21-30

Ghannoum O, Conroy JP, Driscoll SP, Paul MJ, Foyer CH, Lawlor DW (2003) Non-stomatal limitations are responsible for drought-induced photosynthetic inhibition in four $\mathrm{C}_{4}$ grasses. New Phytol 159: 599-608

Gupta AS, Berkowitz GA (1988) Chloroplast osmotic adjustment and water stress effects on photosynthesis. Plant Physiol 88: 200-206

Hemaprabha G, Nagarajan R, Alarmelu S (2004) Response of sugarcane genotypes to water deficit stress. Sugar Technol 6: $165-168$

Hemaprabha G, Nagarajan R, Alarmelu S, Natarajan US (2006) Parental potential of sugarcane clones for drought resistance breeding. Sugar Technol 8: 59-62

Inman-Bamber NG (2004) Sugarcane water stress criteria for irrigation and drying off. Field Crops Res 89: 107-122

Inman-Bamber NG, Smith DM (2005) Water relations in sugarcane and response to water deficits. Field Crops Res 92: 185-202

Ishaq MN, Olaoye G (2009) Cane yield attributes and heritability of juice quality characters in sugarcane under moisture deficit conditions. Sugar Technol 11:360-367

Loggini B, Scartazza A, Brugnoli E, Navari-Izzo F (1999) Antioxidative defense system, pigment composition, and photosynthetic efficiency in two wheat cultivars subjected to drought. Plant Physiol 119: 1091-1100

Maxwell K, Johnson GN (2000) Chlorophyll fluorescence-a practical guide. J Exp Bot 51: 659-668

Müller P, Li XP, Niyogi KK (2001) Non-photochemical quenching. A response to excess light energy. Plant Physiol 125: 1558-1566

Murashige T, Skoog F (1962) A revised medium for rapid growth and bioassays with tobacco tissue cultures. Physiol Plant 15: 473-497

Omasa K, Takayama K (2003) Simultaneous measurement of stomatal conductance, non-photochemical quenching, and photochemical yield of photosystem II in intact leaves by thermal and chlorophyll fluorescence imaging. Plant Cell Physiol 44: $1290-1300$

Queiroz RJB, dos Santos DMM, Ferraudo AS, Carlin SD, Silva MA (2011) Biochemical and physiological responses of sugarcane cultivars to soil water deficiencies. Sci Agric 68: 469-476

Rai MK, Kalai RK, Singh R, Ganola MP, Dhawan AK (2011) Developing stress tolerant plants through in vitro selection-An overview of the recent progress. Environ Exp Bot 71: 89-98

Rodrigues FA, de Laia ML, Zingaretti SM (2009) Analysis of gene expression profiles under water stress in tolerant and sensitive sugarcane plants. Plant Sci 176: 286-302

Rutherford RS(1989) The assessment of proline accumulation as a mechanism of drought resistance in sugarcane. Proceeding of the South African Sugar Technologists' Association pp. 136-141

Shabala SN, Shabala SI, Martynenko AI, Babourina O, Newman IA (1998) Salinity effect on bioelectric activity, growth, $\mathrm{Na}^{+}$ accumulation and chlorophyll fluorescence of maize leaves: a comparative survey and prospects for screening. Aust J Plant Physiol 25: 609-616

Silva MA, da Silva JAG, Enciso J, Sharma V, Jifon J (2008) Yield components as indicators of drought tolerance of sugarcane. Sci Agric 65: 620-627

Silva MA, Jifon JL, da Silva JAG, Sharma V (2007) Use of physiological parameters as fast tools to screen for drought tolerance in sugarcane. Braz J Plant Physiol 19: 193-201 
Silva MA, Jifon J, Sharma V, da Silva JAG, Caputo MM, Damaj MB, Guimarães ER, Ferro MIT (2011) Use of physiological parameters in screening drought tolerance in sugarcane genotypes. Sugar Technol 13: 191-197

Smit MA, Singels A (2006) The response of sugarcane canopy development to water stress. Field Crops Res 98: 91-97

Suprasanna P, Patade VY, Desai NS, Devarumath RM, Kawar PG, Pagariya MC, Ganapathi A, Manickavasagam M, Babu KH (2011) Biotechnological developments in sugarcane improvement: An overview. Sugar Technol 13: 322-335

Thapa G, Dey M, Sahoo L, Panda SK (2011) An insight into the drought stress induced alterations in plants. Biol Plant 55: 603-613
Vasantha S, Alarmelu S, Hemaprabha G, Shanthi RM (2005) Evaluation of promising sugarcane genotypes for drought. Sugar Technol 7: 82-83

Waclawovsky AJ, Sato PM, Lembke CG, Moore PH, Souza GM (2010) Sugarcane for bioenergy production: An assessment of yield and regulation of sucrose content. Plant Biotechnol $J$ 8: 263-276

Wagih ME, Ala A, Musa Y (2003) Biomass analysis and selection of sugarcane genotypes for drought tolerance. Sugar Technol 5: 257-263

Wagih ME, Ala A, Musa Y (2004) Regeneration and evaluation of sugarcane somaclonal variants for drought tolerance. Sugar Technol 6: 35-40 